\title{
An Analysis of Varnish and Impregnation Processes for Combustion Temperature of Scotch Pine
}

\author{
Musa Atar, Nihat Döngel, Hamza Çinar* \\ Wood Products Industrial Engineering Department, Technology Faculty, Gazi University, Ankara, Turkey \\ Email: ${ }^{*}$ Hamzacinar@gazi.edu.tr
}

Received 3 November 2014; accepted 27 November 2014; published 16 January 2015

Copyright (C) 2015 by authors and Scientific Research Publishing Inc.

This work is licensed under the Creative Commons Attribution International License (CC BY). http://creativecommons.org/licenses/by/4.0/

c) (i) Open Access

\section{Abstract}

This study was performed to determine the effects of varnishing after impregnation with boron compounds on the combustion properties of Scotch pine. For this purpose, test samples prepared from Scotch pine (Pinus sylvestris Lipsky) wood were impregnated according to ASTM-D 1413-99 standard with boric acid $(\mathrm{Ba})$ and borax $(\mathrm{Bx})$ by vacuum technique. After impregnation, surfaces were coated by cellulosic (Cv), synthetic (Sn), polyurathane $(\mathrm{Pu})$, waterborne $(\mathrm{Wb})$, acrylic $(\mathrm{Ac})$ and acid hardening (Ah) varnishes in accordance with ASTM D-3023 standard and then, combustion temperature was determined. According to material and process type, combustion temperature was the highest in Bx and $\mathrm{Wb}$ in flame source combustion (FSC), the lowest in Ba and Ac without flame source combustion (WFSC). According to combustion type, impregnation material and varnish type, combustion temperature was the highest in FSC, borax and cellulosic varnish combination and the lowest in WFSC, boric acid and acid hardening varnish combination. In conclusion, impregnation materials decrease while varnishes increase the combustion temperature of Scotch pine wood.

\section{Keywords}

Combustion, Boric Acid, Borax, Varnishes, Impregnation, Scotch Pine

\section{Introduction}

Wood is an organic, hygroscopic and anisotropic material. Properties of wood for thermal, acoustic, electrical, mechanical, aesthetic and constructive aspects are very suitable to use and also possible to build a comfortable

\footnotetext{
"Corresponding author.
}

How to cite this paper: Atar, M., Döngel, N. and Çinar, H. (2015) An Analysis of Varnish and Impregnation Processes for Combustion Temperature of Scotch Pine. Materials Sciences and Applications, 6, 78-85. 
house using only wooden products. However, wood shows low resistance against fire and high temperatures according to the study of Bednarek and Kaliszuk [1]. At present, for the crucial importance of fire security, all types of professionals such as architects, interior designers, and furniture manufacturers give a great importance for increasing the resistance of wood material against fire. A number of authors, e.g. Bednarek and Kaliszuk [1], Goldstein [2], Levan and Widany [3], Keskin et al. [4] and Yapici et al. [5] studied the theories of the combustion of wood and its control. The reason is that wood materials are easily burnt by themselves when the temperature reaches to $275^{\circ} \mathrm{C}$ or with an inflammable material at lower temperatures. In spite of making efforts to increase the resistance against fire and high temperatures, wood materials wholly incombustible is almost impossible. However, combustion properties are mainly improved by processing wood with some chemical materials to increase the fire resistance.

Furniture coated only with paint and varnish has surface protection only for two years. However, varnishing and painting after the impregnation with materials having appropriate water-repellent are important for longterm utilization against biotic and abiotic effects, photochemical degradation, dimensional changes, biological factors and fire [1] [5]-[7]. Because of its combustion and inflammation properties, Feist [8] states that wood materials must be processed with chemical materials increasing fire resistance.

Some other studies also suggest that painting and varnishing with water-repellent materials after impregnating with boron make wood more resistant to environmental conditions [9]. Impregnating of wood material with the solution of copper, chrome and salt is an important process in terms of physical effects [10].

In addition to known combustion literature, it is also important to determine the effects of impregnation and varnishing processes on fire resistance. From the backgrounds drawn, this study aims to determine and discuss the effects of varnish and impregnation processes on combustion properties of Scotch pine with various varnishes after impregnation with boric acid (Ba) and borax (Bx).

\section{Materials and Methods}

\subsection{Materials}

\subsubsection{Wood Type}

Smaples of Scotch pine (Pinus sylvestris Lipsky) were randomly chosen from timber suppliers of siteler region of Ankara, Turkey. A blending process was carried out in order to prepare control and experimental samples. Accordingly, non-deficient, proper, knotless, normally grown (without zone line, without reaction wood and without decay, insect mushroom damages) wood materials were selected without defects according to TS 2476 [11].

\subsubsection{Varnish Types}

Cellulosic $(\mathrm{Cv})$, synthetic $(\mathrm{Sn})$, polyurethane $(\mathrm{Pu})$, waterborne $(\mathrm{Wb})$, acrylic $(\mathrm{Ac})$ and acid hardening $(\mathrm{Ah})$ varnishes were used according to the instructions of the producer [12]. Technical specifications of varnishes are given in Table 1.

\subsubsection{Impregnation Types}

The impregnation chemicals of borax and boric acid were used for the study. Properties of boric acid and borax for impregnation are given Table 2.

As a result of using the fresh solution in every impregnation process, there were no important changes in the acidity and density of solutions before and after the impregnation.

\subsection{Method}

\subsubsection{Preparation of Test Samples}

The rough drafts for the preparation of test and control samples were cut from the sapwood parts of massive woods with a dimension of $190 \times 140 \times 15 \mathrm{~mm}$ and conditioned at $20^{\circ} \mathrm{C} \pm 2^{\circ} \mathrm{C}$ temperature and $65 \% \pm 3 \%$ relative humidity till they reach $12 \%$ humidity distribution. The air-dry samples with a dimension of $13 \times 13 \times 76$ $\mathrm{mm}$ were cut from the drafts for impregnation and varnishing. The test samples were impregnated with 5.5\% boric acid and 5\% borax according to ASTM D-1413-99 [13]. Accordingly, the samples were exposed to a 700 $\mathrm{mm} / \mathrm{Hg}^{-1}$ prevacuum for 60 minutes and then were held in a solution under normal atmospheric pressure for 60 
Table 1. Some properties of varnishes.

\begin{tabular}{ccccccc}
\hline Type of varnish & pH value & $\begin{array}{c}\text { Density } \\
\left(\mathrm{g} \cdot \mathrm{cm}^{-3}\right)\end{array}$ & $\begin{array}{c}\text { Viscosity } \\
(\mathrm{snDINCup} / 4 \mathrm{~m})\end{array}$ & $\begin{array}{c}\text { Amount applied } \\
\left(\mathrm{g} \cdot \mathrm{m}^{-2}\right)\end{array}$ & $\begin{array}{c}\text { Nozzle gap } \\
(\mathrm{mm})\end{array}$ & $\begin{array}{c}\text { Air pressure } \\
\text { (bar) }\end{array}$ \\
\hline Pu (filler) & 5.94 & 0.98 & 18 & 125 & 1.8 & 2 \\
Pu (finishing) & 4.01 & 0.99 & 18 & 125 & 1.8 & 2 \\
Sn & - & 0.94 & 18 & 100 & - & - \\
Wb ASTM D-17 (primer) & 9.17 & 1.014 & 18 & 100 & 1.3 & 1 \\
Wb ASTM D-65 (filler) & 9.30 & 1.015 & 18 & 67 & 1.3 & 1 \\
Wb ASTM D-45 (finishing) & 8.71 & 1.031 & 18 & 67 & 1.3 & 1 \\
Cv & 2.9 & 0.955 & 20 & 125 & 1.8 & 3 \\
Cv (finishing) & 3.4 & 0.99 & 20 & 125 & 1.8 & 3 \\
Ac (filler) & 4.3 & 0.95 & 18 & 125 & 1.8 & 2 \\
Ac (finishing) & 4.6 & 0.97 & 18 & 125 & 1.8 & 2 \\
Ah (finishing) & 8.0 & 0.99 & 18 & 100 & 1.8 & 3 \\
\hline
\end{tabular}

Table 2. Characteristics of impregnations.

\begin{tabular}{|c|c|}
\hline Boric acid $\left(\mathrm{H}_{3} \mathrm{BO}_{3}\right)$ & \\
\hline Compound & $56.30 \% 1 / 2 \quad \mathrm{~B}_{2} \mathrm{O}_{3}, 43.70 \% \mathrm{H}_{2} \mathrm{O}$ \\
\hline Molecular weight & 61.84 \\
\hline Density & $1.435 \mathrm{~g} / \mathrm{cm}^{3}$ \\
\hline Molten & $800-815 \mathrm{~kg} / \mathrm{m}^{3}$ \\
\hline Melting point & $171^{\circ} \mathrm{C}$ \\
\hline \multicolumn{2}{|l|}{$\operatorname{Borax}\left(\mathrm{Na}_{2} \mathrm{~B}_{4} \mathrm{O}_{7} \cdot 5 \mathrm{H}_{2} \mathrm{O}\right)$} \\
\hline Compound & $21.28 \% \mathrm{Na}_{2} \mathrm{O}, 47.80 \% \mathrm{~B}_{2} \mathrm{O}_{3}, 30.92 \% \mathrm{H}_{2} \mathrm{O}$ \\
\hline Molecular weight & 291.35 \\
\hline Density & $1.815 \mathrm{~g} / \mathrm{cm}^{3}$ \\
\hline Molten & $2.980 \mathrm{~kg} / \mathrm{m}^{3}$ \\
\hline Melting point & $741^{\circ} \mathrm{C}$ \\
\hline
\end{tabular}

minutes to allow the diffusion of the impregnation material. The processes were carried out at $20^{\circ} \mathrm{C} \pm 2^{\circ} \mathrm{C}$. Retention of impregnation material $(R)$ was calculated by the formula:

$$
R=\frac{G \cdot C}{V} \times 10, G=T_{2}-T_{1}
$$

where, $G$ is the amount of impregnation solution absorbed by the specimen, $T_{2}$ is the specimen weight after the impregnation, $T_{1}$ is the specimen weight before the impregnation, $C$ is the concentration (\%) of the impregnation solution and $V$ is the volume of the samples. Impregnated test samples were kept under $20^{\circ} \mathrm{C} \pm 2^{\circ} \mathrm{C}$ temperature and $65 \% \pm 3 \%$ relative humidity until they reach to a stable weight.

\subsubsection{Varnishing}

Test samples were varnished according to ASTM D-3023 [14]. The surfaces of samples were sanded with sanding papers to remove the fiber swellings and dusts were cleaned before varnishing. The application of varnishing was very significant to make varnish layers durable against to various effects. Consequently, using material in 
the experiments was stored until their usage to prevent loss of properties. The description of the producer was taken into care for the composition of solvent and hardener ratio and two finishing layers were applied after the filling layer. Spray nozzle distance and pressure were adjusted and moved in parallel to the specimen surface at a distance of $20 \mathrm{~cm}$. Varnishing was performed under $20^{\circ} \mathrm{C} \pm 2^{\circ} \mathrm{C}$ temperature and $65 \% \pm 3 \%$ relative humidity conditions.

\subsubsection{Combustion Test}

Combustion tests were carried out in accordance with ASTM E-160-50 [15]. Accordingly, before the combustion test, impregnated samples were conditioned at $27^{\circ} \mathrm{C}$ temperature and $30 \%$ relative humidity in conditioning room till reaching to $7 \%$ humidity. Every sample group weighted before test was stowed on wire stand. Samples on every stand were put vertically with respect to below and above stands. Fire distance from the below maker type exit was fixed to $25 \pm 1.3 \mathrm{~cm}$ when the device was empty and gase pressure was fixed to $0.5 \mathrm{~kg} / \mathrm{cm}^{2}$ in manometer. When the gase burned, temperature was tried to be set at $315^{\circ} \mathrm{C} \pm 8^{\circ} \mathrm{C}$ in the funnel which had a thermocouple. Flame source was centered below sample pile and flame source combustion was continued for 3 minutes. After extinguishing of flame source, without flame source combustion was carried out. A temperature change of combustion was determined with thermometer.

\subsubsection{Data Analysis}

Multiple variance analysis was used to determine in both of natural and impregnated samples, as well as the effects of impregnation material on combustion with or without flame source. Based on the significance of Duncan Test, each test group was compared with one another and itself.

\section{Results}

\subsection{Retention}

Proportion of retention is given in Table 3.

The highest result for retention proportion of Scotch pine was observed in boric acid while the lowest result was found for borax. Types of impregnations and solution concentrations were found effective on the retention amount.

Dry film thickness and solid amounts of varnish types are given in Table 4.

The thickness values of the varnish layers were measured with a comparator with the sensitivity of $5 \mu \mathrm{m}$. The highest value was observed in acid hardening varnish samples with $104 \mu \mathrm{m}$. The lowest dry film thickness of 93 $\mu \mathrm{m}$ was obtained from water-based varnish samples.

\subsection{Combustion Temperature}

Average temperature values for combustion type, impregnation materials and varnish types are given in Table 5.

The highest value for temperature of combustion was found in FSC while the lowest was observed in WSFC. According to the types of impregnation material, the highest temperature was observed in Bx, and the lowest was found in Ba while control sample had higher value more than Bx and Ba. For varnishes, the highest result for combustion temperature was obtained from Wb varnish, while the lowest result was found in Pu varnish. However, the unvarnished samples have the lowest temperature. Accordingly, in general it is possible to say that impregnation materials decrease while varnishes increase the combustion temperature.

A double combination of average temperature values according to combustion type and impregnation material, impregnation material and varnish type, combustion type and varnish type are given in Table 6.

Temperature value was the highest in FSC + Bx, the lowest in WFSC + Ba according to combustion types.

Table 3. Proportion of retention.

\begin{tabular}{cc}
\hline Impregnation chemicals & Retention (wt\%) \\
\hline Control & - \\
Borax & 9.1 \\
Boric acid & 16.90 \\
\hline
\end{tabular}


Table 4. Dry film thickness of varnish types.

\begin{tabular}{ccccccc}
\hline \multirow{2}{*}{$\begin{array}{c}\text { Layer } \\
\text { thickness }\end{array}$} & \multicolumn{5}{c}{ Varnish types } \\
\cline { 2 - 6 } & Acrylic & Acid hardening & Cellulosic & Polyurethane & Synthetic & Water-based \\
\hline Dry film $(\mu \mathrm{m})$ & 102 & 104 & 96 & 101 & 99 & 93 \\
\hline
\end{tabular}

Table 5. Average temperature values of different processes and materials.

\begin{tabular}{|c|c|c|}
\hline \multicolumn{2}{|c|}{ Types of combustion* } & \multirow{2}{*}{$\begin{array}{c}\text { Temperature }\left({ }^{\circ} \mathrm{C}\right)^{2} \\
451.624 \mathrm{a}\end{array}$} \\
\hline Flame source combustion & $(\mathrm{FSC})$ & \\
\hline Without flame source combustion & (WFSC) & $425.984 \mathrm{~b}$ \\
\hline \multicolumn{3}{|c|}{ Impregnation materials** $^{* *}$} \\
\hline Control & (Co) & $495.067 \mathrm{a}$ \\
\hline Boric acid & $(\mathrm{Ba})$ & 391.515 c \\
\hline Borax & $(\mathrm{Bx})$ & $429.831 \mathrm{~b}$ \\
\hline \multicolumn{3}{|c|}{ Varnishes $^{* * *}$} \\
\hline Unvarnished & (Uv) & $375.250 \mathrm{~g}$ \\
\hline Cellulosic & $(\mathrm{Cv})$ & $465.991 \mathrm{c}$ \\
\hline Synhetic & $(\mathrm{Sn})$ & $449.056 \mathrm{~d}$ \\
\hline Polyurethane & $(\mathrm{Pu})$ & $403.500 \mathrm{f}$ \\
\hline Water-based & $(\mathrm{Wb})$ & $479.333 \mathrm{a}$ \\
\hline Acrylic & (Ac) & $475.944 \mathrm{~b}$ \\
\hline Acid hardening & $(\mathrm{Ah})$ & $422.556 \mathrm{e}$ \\
\hline
\end{tabular}

${ }^{a}$ Different letters in a column refers to significant differences among types of processes and materials at 0.05 confidence level $\left({ }^{*} \mathrm{LSD}_{0.5}: 1.661,{ }^{* *} \mathrm{LSD}_{0.5}: 2.034,{ }^{* * *} \mathrm{LSD}_{0.5}\right.$ : 3.107), FSC: Flame source combustion, WFSC: Without flame source combustion, Co: Unimpregnated samples, Ba: Boric acid, Bx: Borax, Uv: Unvarnished, Cv: Cellülosic, Sn: Synthetic, Pu: Polyurathane, Wb: Water borne, Ac: Acrilic, Ah: Acid hardening.

For the combination of impregnations and varnishes, the highest value was obtained in $\mathrm{Bx}+\mathrm{Wb}$, the lowest one was obtained in $\mathrm{Ba}+\mathrm{Ah}$ respectively. Accordingly, impregnations show a significant decreasing impact on combustion temperature. In accordance with the combustion temperature and varnish combinations' results, the highest value was found in FSC + Cv while the lowest value was obtained in WFSC + Ah. The results for varnishes indicate an important increasing impact for combustion temperature.

Results of multiple variance analysis for impact of combustion type, impregnation material and varnish type for temperature value are given in Table 7.

Effects of combustion type, impregnation material and varnish type on combustion temperature were found tobe significant $(\alpha=0.05)$.

Duncan test results are given in Table 8 to indicate the importance of differences between the groups.

According to Table 8, the highest combustion temperature was observed in the experiment samples which were varnished with synthetic varnished and not impregnated. The samples varnished with acid hardening gave the lowest result. However, after impregnation and varnishing, the highest result was obtained from the samples which were varnished with cellulosic varnish and impregnated with borix acid. The lowest value was found from those of acid hardening varnish samples which were impregnated with boric acid. The results associated with these values are shown in Figure 1.

\section{Conclusions}

Acid hardening varnishes samples give the highest thickness values of dry film varnish layer with $104 \mu \mathrm{m}$, while water-based varnishes give the lowest dry film thickness with the value of $93 \mu \mathrm{m}$ respectively. Impregnations are significantly effective on the retention amount, and boric acid gives better results than borax. 
Table 6. Temperature average values for the combination of processes and materials.

\begin{tabular}{|c|c|c|}
\hline \multicolumn{2}{|c|}{ Combustions \& Impregnations ${ }^{*}$} & Temperature $\left({ }^{\circ} \mathrm{C}\right)^{\mathrm{a}}$ \\
\hline \multicolumn{2}{|c|}{ FSC } & $480.610 \mathrm{~b}$ \\
\hline \multicolumn{2}{|c|}{$\mathrm{FSC}+\mathrm{Ba}$} & $416.554 \mathrm{~d}$ \\
\hline \multicolumn{2}{|c|}{$\mathrm{FSC}+\mathrm{Bx}$} & $457.710 \mathrm{c}$ \\
\hline \multicolumn{2}{|c|}{ WFSC } & $509.524 \mathrm{a}$ \\
\hline \multicolumn{2}{|c|}{$\mathrm{WFSC}+\mathrm{Ba}$} & $366.476 \mathrm{f}$ \\
\hline \multicolumn{2}{|c|}{$\mathrm{WFSC}+\mathrm{Bx}$} & $401.952 \mathrm{e}$ \\
\hline \multicolumn{2}{|c|}{ Varnishes \& Impregnations $^{* *}$} & $\left({ }^{\circ} \mathrm{C}\right)^{\mathrm{a}}$ \\
\hline Co & - & $413.917 \mathrm{gh}$ \\
\hline $\mathrm{Ba}$ & - & $341.833 \mathrm{~m}$ \\
\hline \multirow[t]{2}{*}{$\mathrm{Bx}$} & - & $370.000 \mathrm{k}$ \\
\hline & $\mathrm{Cv}$ & 517.217 c \\
\hline \multirow[t]{3}{*}{$\mathrm{Cv}$} & $+\mathrm{Ba}$ & $417.773 \mathrm{~g}$ \\
\hline & $+\mathrm{Bx}$ & 462.983 e \\
\hline & $\mathrm{Sn}$ & $554.500 \mathrm{a}$ \\
\hline \multirow[t]{3}{*}{ Sn } & $+\mathrm{Ba}$ & $390.833 \mathrm{j}$ \\
\hline & $+\mathrm{Bx}$ & 401.8331 \\
\hline & $\mathrm{Pu}$ & $447.000 \mathrm{f}$ \\
\hline \multirow[t]{3}{*}{$\mathrm{Pu}$} & $+\mathrm{Ba}$ & 352.333 l \\
\hline & $+\mathrm{Bx}$ & $411.167 \mathrm{~h}$ \\
\hline & $\mathrm{Wb}$ & $528.000 \mathrm{~b}$ \\
\hline \multirow[t]{3}{*}{$\mathrm{Wb}$} & $+\mathrm{Ba}$ & $445.500 \mathrm{f}$ \\
\hline & $+\mathrm{Bx}$ & $464.500 \mathrm{e}$ \\
\hline & Ac & $530.500 \mathrm{~b}$ \\
\hline \multirow[t]{3}{*}{ Ac } & $+\mathrm{Ba}$ & $450.333 \mathrm{f}$ \\
\hline & $+\mathrm{Bx}$ & $447.000 \mathrm{f}$ \\
\hline & $\mathrm{Ah}$ & $474.333 \mathrm{~d}$ \\
\hline \multirow[t]{2}{*}{$\mathrm{Ah}$} & $+\mathrm{Ba}$ & $342.000 \mathrm{~m}$ \\
\hline & $+\mathrm{Bx}$ & $451.333 \mathrm{f}$ \\
\hline \multicolumn{2}{|c|}{ Combustions \& Varnishes ${ }^{* * *}$} & $\left({ }^{\circ} \mathrm{C}\right)^{\mathrm{a}}$ \\
\hline \multirow{7}{*}{ FSC } & FSC & $318.389 \mathrm{k}$ \\
\hline & $+\mathrm{Cv}$ & 512.427 a \\
\hline & $+\mathrm{Sn}$ & $502.889 \mathrm{~b}$ \\
\hline & $+\mathrm{Pu}$ & $384.8899_{1}$ \\
\hline & $+\mathrm{Wb}$ & $498.667 \mathrm{~b}$ \\
\hline & $+\mathrm{Ac}$ & 474.889 c \\
\hline & $+\mathrm{Ah}$ & $469.222 \mathrm{~d}$ \\
\hline \multirow{7}{*}{ WFSC } & WFSC & $432.111 \mathrm{f}$ \\
\hline & $+\mathrm{Cv}$ & $419.556 \mathrm{~g}$ \\
\hline & $+\mathrm{Sn}$ & $395.222 \mathrm{~h}$ \\
\hline & $+\mathrm{Pu}$ & $422.111 \mathrm{~g}$ \\
\hline & $+\mathrm{Wb}$ & $460.000 \mathrm{e}$ \\
\hline & $+\mathrm{Ac}$ & $477.000 \mathrm{c}$ \\
\hline & $+\mathrm{Ah}$ & 375.889 j \\
\hline
\end{tabular}

${ }^{a}$ Different letters in a column refers to significant differences among different interactions of types of combustion, varnish and impregnation materials, level $\left({ }^{*} \mathrm{LSD}_{0.5}: 2.876,{ }^{* *} \mathrm{LSD}_{0.5}: 5.381,{ }^{* * *} \mathrm{LSD}_{0.5}: 4.394\right)$. 
Table 7. Multiple variance analysis results.

\begin{tabular}{cccccc}
\hline Source & Degrees of freedom & Sum of squares & Mean square & F value & P $\%$ 5 (Sig) \\
\hline Factor A $^{\text {a }}$ & 1 & 20708.916 & 20708.916 & 933.6655 & 0.0000 \\
Factor B $^{\text {b }}$ & 6 & 169483.828 & 28247.305 & 1273.5353 & 0.0000 \\
AB & 6 & 180648.406 & 30108.068 & 1357.4281 & 0.0000 \\
Factor C & 2 & 230253.667 & 115126.834 & 5190.5159 & 0.0000 \\
AC & 2 & 47044.547 & 23522.274 & 1060.5063 & 0.0000 \\
BC & 12 & 52383.764 & 4365.314 & 196.8110 & 0.0000 \\
ABC & 12 & 101812.184 & 8484.349 & 382.5185 & 0.0000 \\
Error & 84 & 1863.139 & 22.180 & & \\
Toplam & 125 & 804198.45 & & & \\
\hline
\end{tabular}

${ }^{\mathrm{a}}$ Factor A: Combustion type (FSC: Flame source combustion, WFSC: Without flame source combustion); ${ }^{\mathrm{b}}$ Factor B: Varnish type (Cv: Cellulosic, Sn: Synthetic, Pu: Polyurathane, Wb: Water-borne, Ac: Acrylic, Ar: Acid hardening); ${ }^{\circ}$ Factor C: Impregnation material (Ba: Boric acid, Bx: Borax).

Table 8. Duncan test results.

\begin{tabular}{|c|c|c|c|c|c|}
\hline Process type & Temp. $\left({ }^{\circ} \mathrm{C}\right)^{\mathrm{a}}$ & Process type & Temp. $\left({ }^{\circ} \mathrm{C}\right)^{\mathrm{a}}$ & Process type & Temp. $\left({ }^{\circ} \mathrm{C}\right)^{\mathrm{a}}$ \\
\hline WFSC + Sn & 590.3 a & $\mathbf{F S C}+\mathbf{C v}$ & $488.8 \mathrm{i}$ & $\mathrm{WFSC}+\mathrm{Ba}+\mathrm{Wb}$ & 412.0 no \\
\hline $\mathrm{WFSC}+\mathrm{Ac}$ & $558.0 \mathrm{~b}$ & $\mathrm{FSC}+\mathrm{Ba}+\mathrm{Wb}$ & $479.0 \mathrm{j}$ & $\mathrm{FSC}+\mathrm{Bx}+\mathrm{Pu}$ & 406.0 ор \\
\hline $\mathrm{WFSC}+\mathrm{Cv}$ & $545.7 \mathrm{c}$ & $\mathrm{FSC}+\mathrm{Bx}+\mathrm{Ac}$ & $468.7 \mathrm{k}$ & WFSC + Ba & $402.0 \mathrm{p}$ \\
\hline WFSC + Wb & $536.0 \mathrm{~d}$ & WFSC & $464.3 \mathrm{k}$ & $\mathrm{WFSC}+\mathrm{Ba}+\mathrm{Pu}$ & $402.0 \mathrm{p}$ \\
\hline $\mathrm{FSC}+\mathrm{Bx}+\mathrm{Cv}$ & $533.3 \mathrm{~d}$ & $\mathrm{FSC}+\mathrm{Ba}+\mathrm{Ac}$ & $453.0 \mathrm{l}$ & $\mathrm{FSC}+\mathrm{Ba}+\mathrm{Ah}$ & $393.3 \mathrm{q}$ \\
\hline $\mathrm{FSC}+\mathrm{Ah}$ & $524.3 \mathrm{e}$ & WFSC + Pu & 448.01 & $\mathrm{WFSC}+\mathrm{Bx}+\mathrm{Cv}$ & $392.7 \mathrm{q}$ \\
\hline $\mathrm{FSC}+\mathrm{Wb}$ & 520.0 ef & $\mathrm{WFSC}+\mathrm{Ba}+\mathrm{Ac}$ & 447.71 & FSC & $363.5 \mathrm{r}$ \\
\hline $\mathrm{FSC}+\mathrm{Sn}$ & 518.7 ef & $\mathrm{FSC}+\mathrm{Pu}$ & $446.0 \mathrm{l}$ & $\mathrm{WFSC}+\mathrm{Ba}+\mathrm{Cv}$ & $320.3 \mathrm{~s}$ \\
\hline $\mathrm{FSC}+\mathrm{Ba}+\mathrm{Cv}$ & $515.2 \mathrm{f}$ & $\mathrm{WFSC}+\mathrm{Bx}+\mathrm{Wb}$ & $432.0 \mathrm{~m}$ & $\mathrm{FSC}+\mathrm{Bx}$ & $310.0 \mathrm{t}$ \\
\hline $\mathrm{FSC}+\mathrm{Ac}$ & $503.0 \mathrm{~g}$ & WFSC + Bx & $430.0 \mathrm{~m}$ & $\mathrm{WFSC}+\mathrm{Bx}+\mathrm{Sn}$ & $304.7 \mathrm{t}$ \\
\hline $\mathrm{FSC}+\mathrm{Bx}+\mathrm{Sn}$ & $499.0 \mathrm{gh}$ & $\mathrm{WFSC}+\mathrm{Bx}+\mathrm{Ac}$ & $425.3 \mathrm{~m}$ & $\mathrm{FSC}+\mathrm{Ba}+\mathrm{Pu}$ & $302.7 \mathrm{t}$ \\
\hline $\mathrm{FSC}+\mathrm{Bx}+\mathrm{Wb}$ & 497.0 ghi & WFSC + Ah & $424.3 \mathrm{~m}$ & $\mathrm{WFSC}+\mathrm{Ba}+\mathrm{Sn}$ & $290.7 \mathrm{u}$ \\
\hline $\mathrm{FSC}+\mathrm{Ba}+\mathrm{Sn}$ & 491.0 hi & $\mathrm{WFSC}+\mathrm{Bx}+\mathrm{Pu}$ & $416.3 \mathrm{n}$ & $\mathbf{W F S C}+\mathbf{B a}+\mathbf{A h}$ & $290.7 \mathrm{u}$ \\
\hline $\mathrm{FSC}+\mathrm{Bx}+\mathrm{Ah}$ & $490.0 \mathrm{i}$ & $\mathrm{WFSC}+\mathrm{Bx}+\mathrm{Ah}$ & 412.7 no & WFSC + Ba & $281.7 \mathrm{v}$ \\
\hline
\end{tabular}

${ }^{\mathrm{a}}$ Different letters in a column refers to significant differences among the different interactions of combustion, varnishes and impregnation materials at 0.05 confidence level $\left(\mathrm{LSD}_{0.5}: 9.811\right)$.

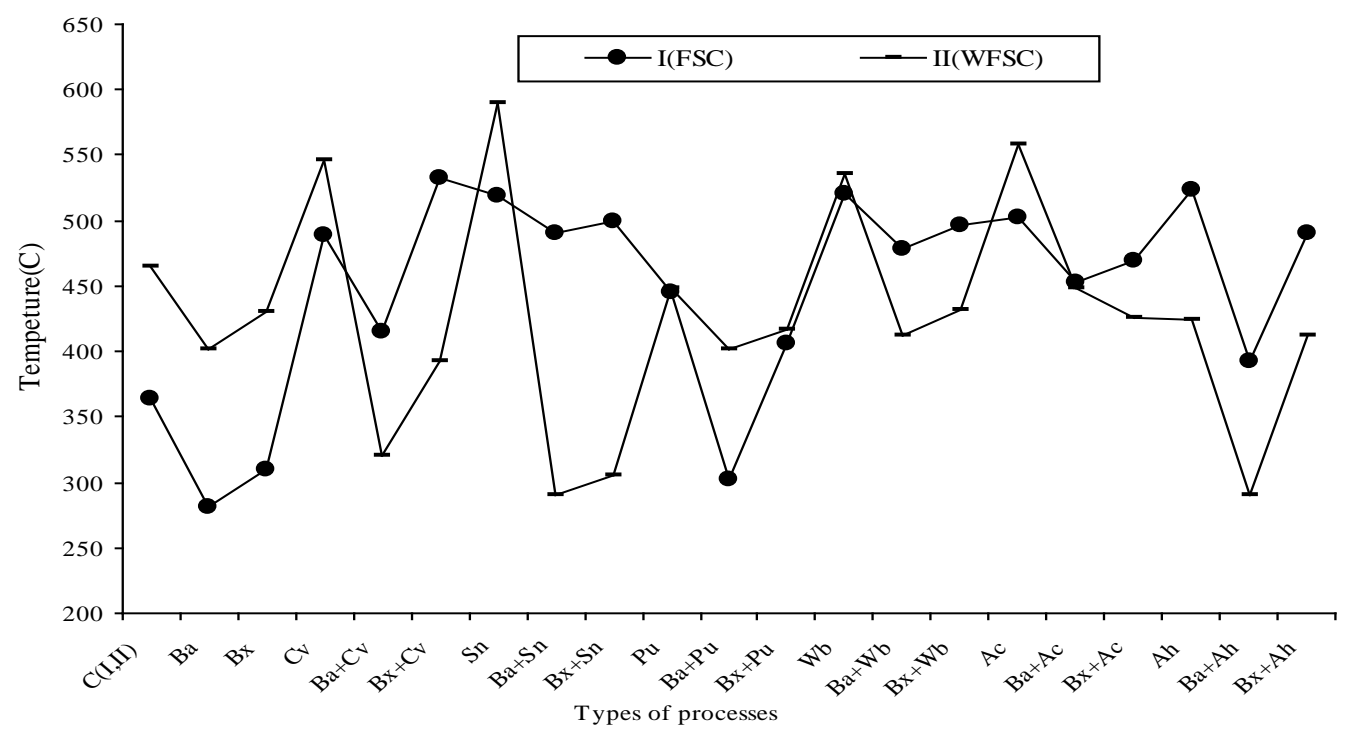

Figure 1. Combustion temperature changes of Scotch pine wood according to type of treatment. 
According to the types of impregnation materials, the highest temperature was observed in borax, and the lowest was found in boric acid while control sample had higher value more than borax and boric acid. For varnishes, the highest result for combustion temperature was obtained from Wb varnish, while the lowest result was found in Pu varnish. However, the unvarnished samples had the lowest temperature. For the combination of impregnations and varnishes, the highest value was obtained in borax + water-based, the lowest one was obtained in boric acid + acid hardening and synthetic varnish respectively.

Accordingly, impregnations show a significant decreasing impact on combustion temperature while the results of varnishes indicate an important increasing impact for combustion temperature. As a result of the study, in general it is possible to say that impregnation materials decrease while varnishes increase the combustion temperature.

\section{References}

[1] Bednarek, Z. and Kaliszuk-Wietecka, A. (2007) Analysis of Fire-Protection Impregnation Influence on Wood Strength. Journal of Civil Engineering Management, 13, 79-85.

[2] Goldstein, I.S. (1973) Deterioration and Protection of Wood from Thermal Attact: Wood Deteration and Its Prevention by Preservation Treatments. Syracuse University Press, Syracuse, 307-339.

[3] Levan, S.L. and Widany, J.E. (1990) Effects of Fire Retardant Treatments on Wood Strength: A Review. Wood and Fiber Science, 22, 113-131.

[4] Keskin, H., Atar, M. and Izciler, M. (2009) Impacts of Impregnation Chemicals on Combustion Properties of the Laminated Wood Materials Produced Combination of Beech and Poplar Veneers. Construction and Building Materials, 23, 634-643. http://dx.doi.org/10.1016/j.conbuildmat.2008.02.006

[5] Yapici, F., Uysal, B., Kurt, S., Esen, R. and Ozcan, C. (2011) Impacts of Impreh-Gnation Chemicals on Finishing Process and Comcustion Properties of Oriental Beech (Fagus Orientalis L.) Wood. Bioresources, 6, 3933-3943.

[6] Evans, P.D., Michell, A.J. and Schmalzl, K. (1992) Studies of the Degradetion and Protection of Wood Surfaces. Wood Science and Technology, 26, 151-163. http://dx.doi.org/10.1007/BF00194471

[7] Atar, M., Keskin, H. and Yavuzcan, H.G. (2004) Varnish Layer Hardness of Oriental Beech (Fagus orientalis Lipsky) Wood as Affected by Impregnation and Color Bleaching. Journal of Coatings Technology (JCT), 1, 498-504.

[8] Feist, W.C. (1988) Weathering of Wood and Its Control by Water Repellent Preservatives. In: Hamel, M.P., Ed., Wood Protection Techniques and the Use of Treated Wood in Construction, Forest Products Society, Madison, 82-88.

[9] Harrow, K.M. (1997) Leachibility of Some Water-Soluble Wood Preservatives, NZ. Wood Science Technology, B32, 33-40.

[10] Sell, J. and Feist, W.C. (1985) Weathering Behaviour of Cromium-Copper-Boron Treated Wood. Holz als Roh und Werkstoff, 43, 518. http://dx.doi.org/10.1007/BF02608035

[11] TS 2476 (1976) Odunda Fiziksel ve Mekaniksel Deneyler İçin Numune Alma Metotları ve Genel Özellikler. T.S.E, Ankara.

[12] DYO (1996) Dewilux, Teknik Bülten. Dewilux Fabrikaları A.Ş, İzmir.

[13] ASTM D-1413-99 (2005) Standart Method of Testing Wood Preservatives by Laboratory Soilblock Cultures. Annual Book of ASTM Standards, 452-460.

[14] ASTM D-3023 (1998) Standard Practice for Determination of Resistance of Factory Applied Coatings on Wood Products of Stain and Reagents. American Society for Testing and Materials.

[15] ASTM E-160-50 (1975) Standard Test Method for Combustible Properties of Treated Wood by the Cribe Test. ASTM, 04.07, 809-813. 
Scientific Research Publishing (SCIRP) is one of the largest Open Access journal publishers. It is currently publishing more than 200 open access, online, peer-reviewed journals covering a wide range of academic disciplines. SCIRP serves the worldwide academic communities and contributes to the progress and application of science with its publication.

Other selected journals from SCIRP are listed as below. Submit your manuscript to us via either submit@scirp.org or Online Submission Portal.
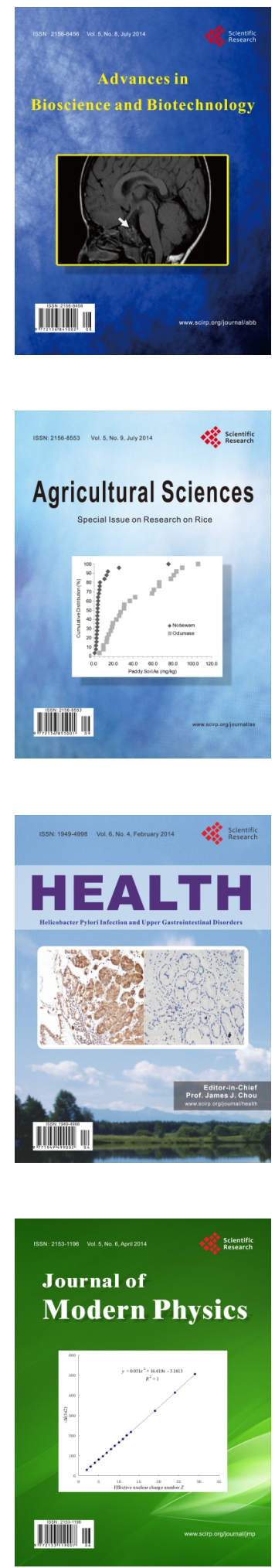
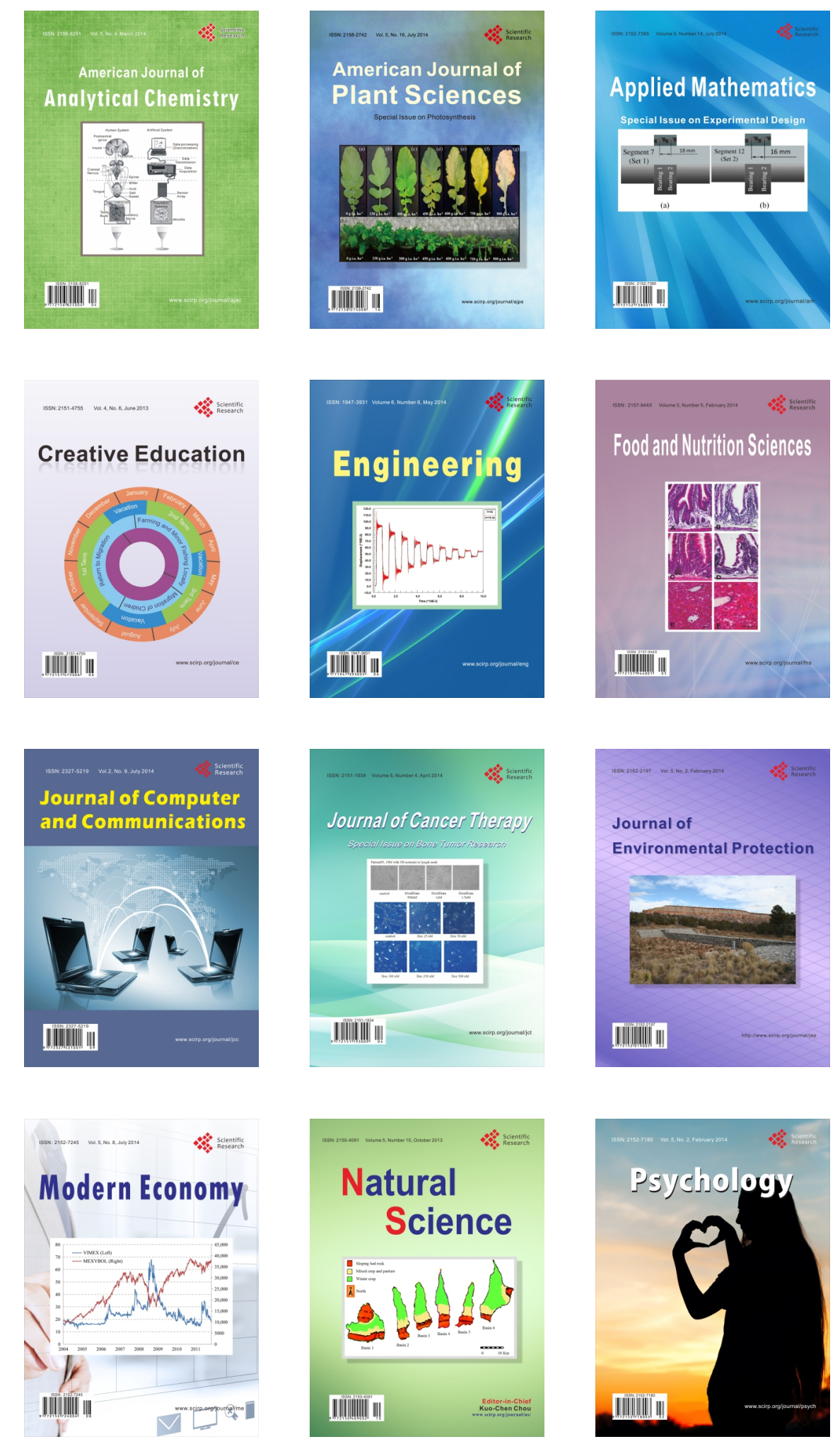